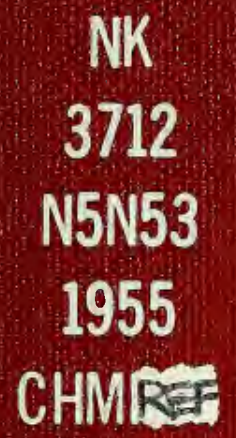


1

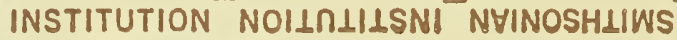
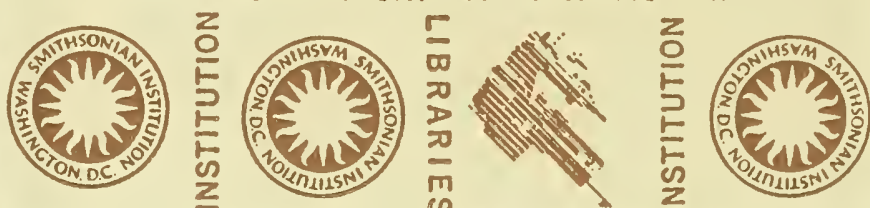

S3IYGYG17 LIBRARIES SMITHSONIAN
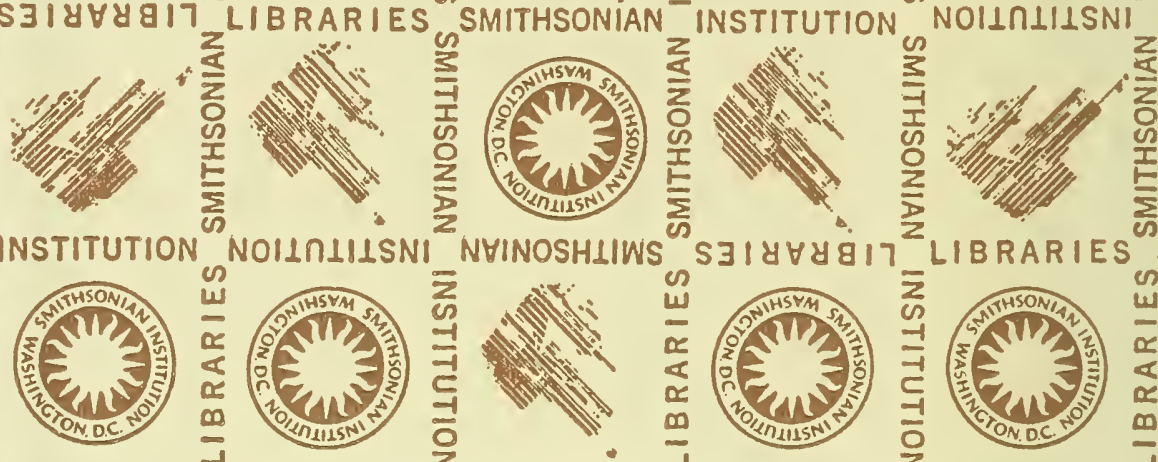

NYINOSHLIWIS
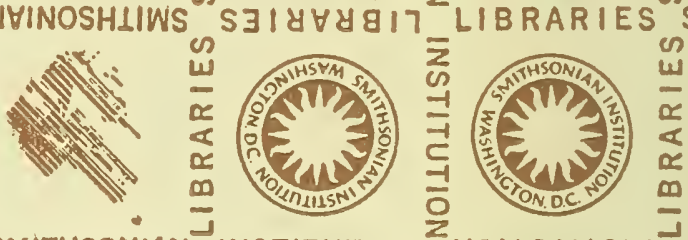

S
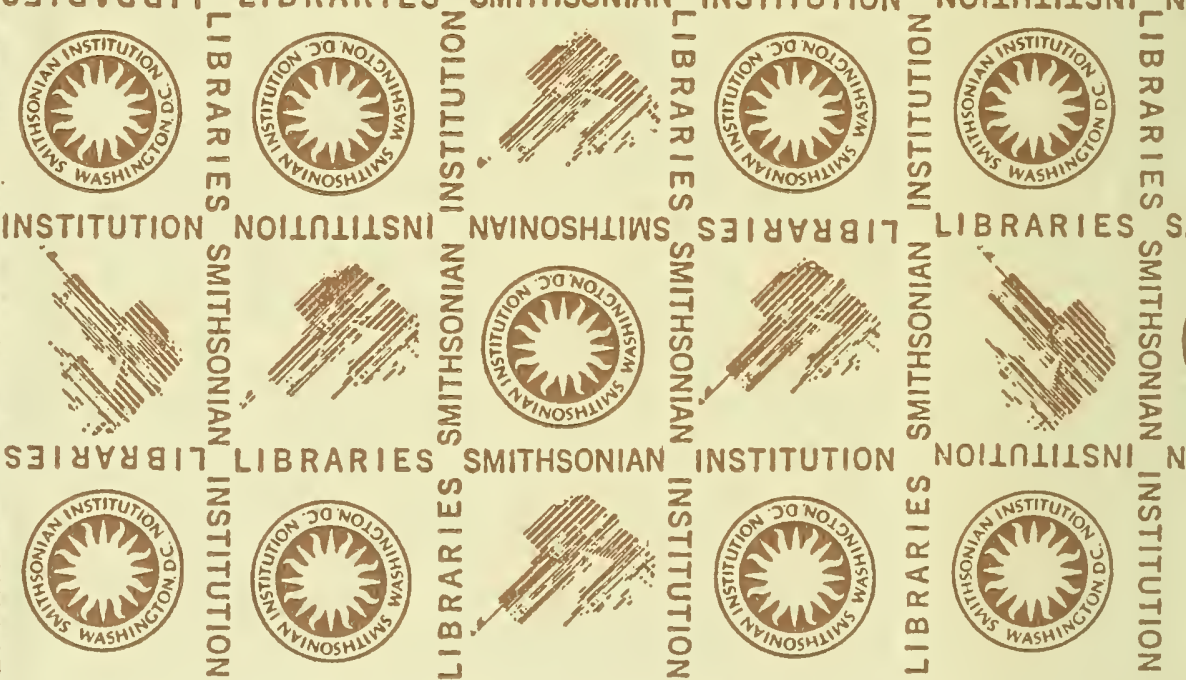

NOILN1IISNI NY
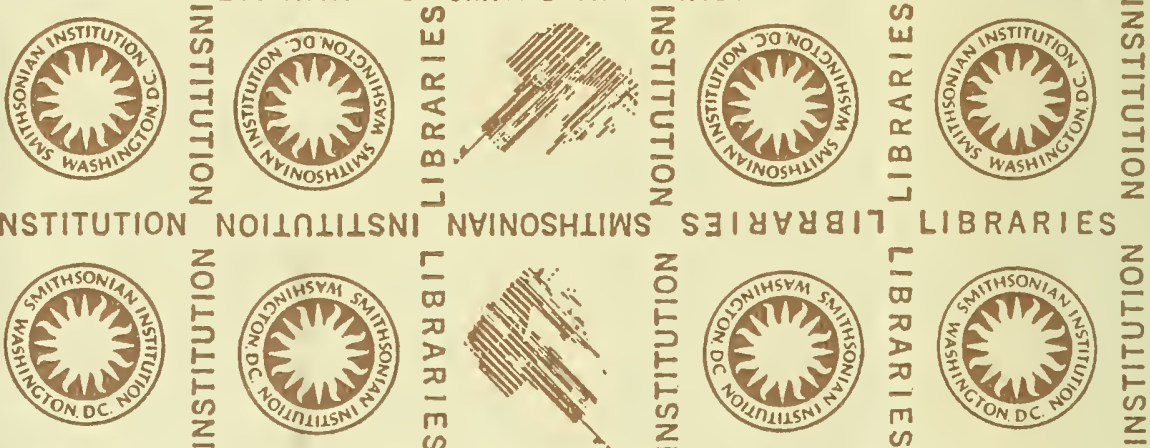

SJI \&

SMITHSONIAN
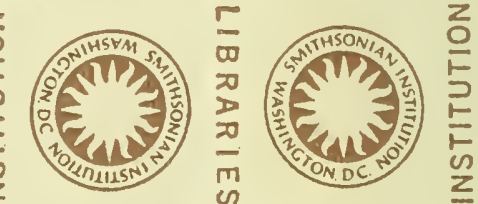

. $\frac{z}{z}$ 네 


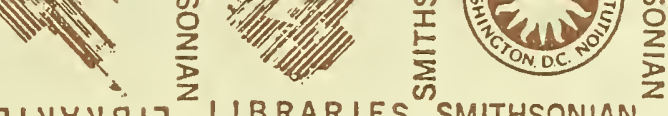

S $\exists I Y \forall Y 817$ LIBRARIES SMITHSONIAN

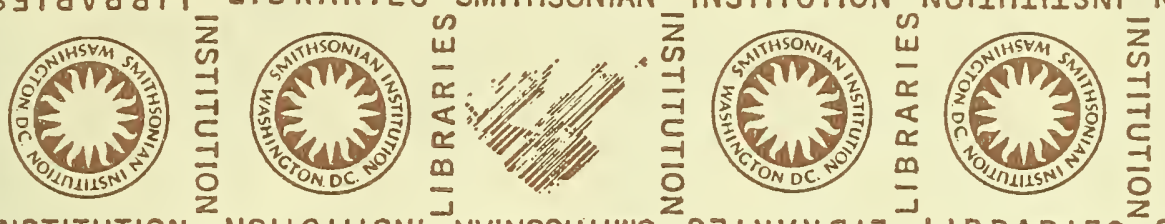

INSTITUTION NOILNIIISNI NHINOSHIIWS
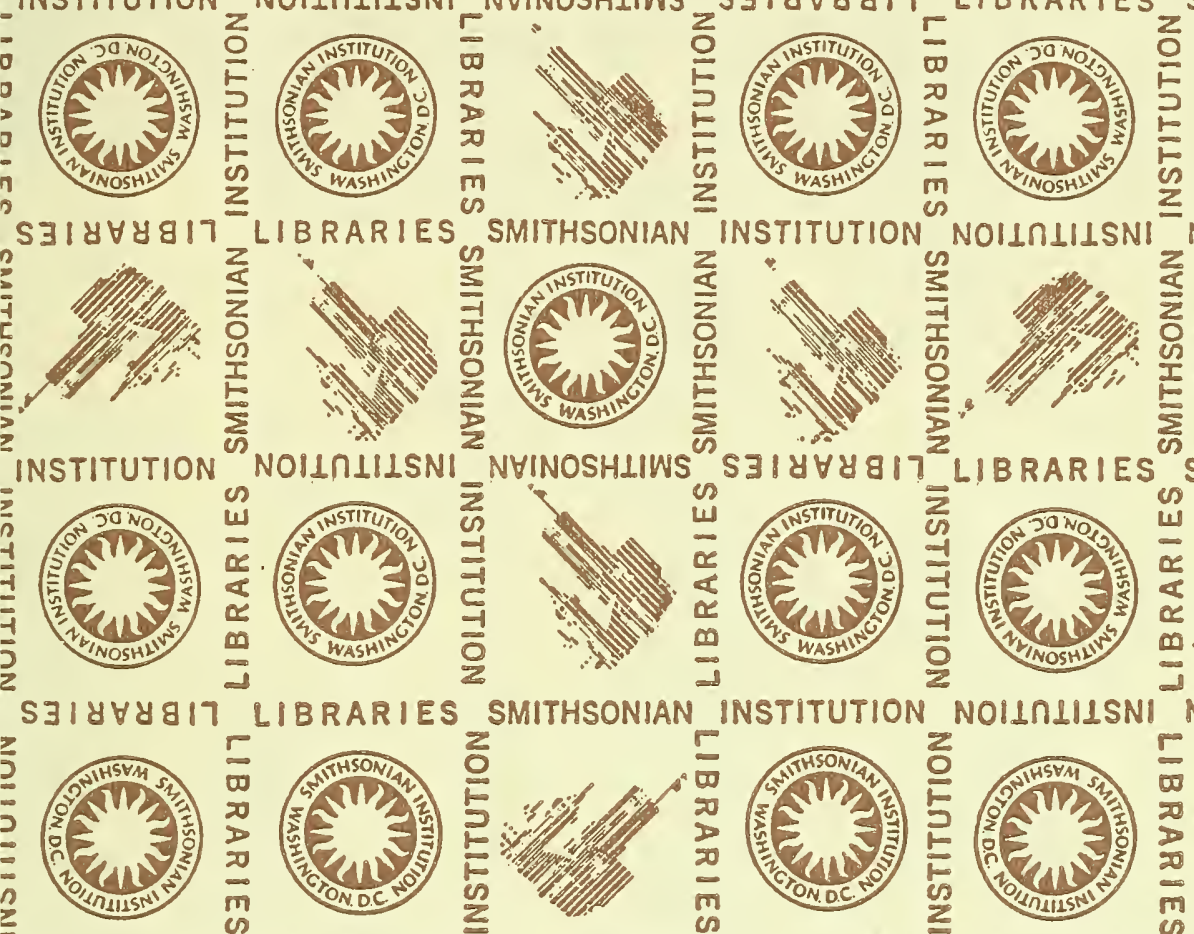

INSTITUTION
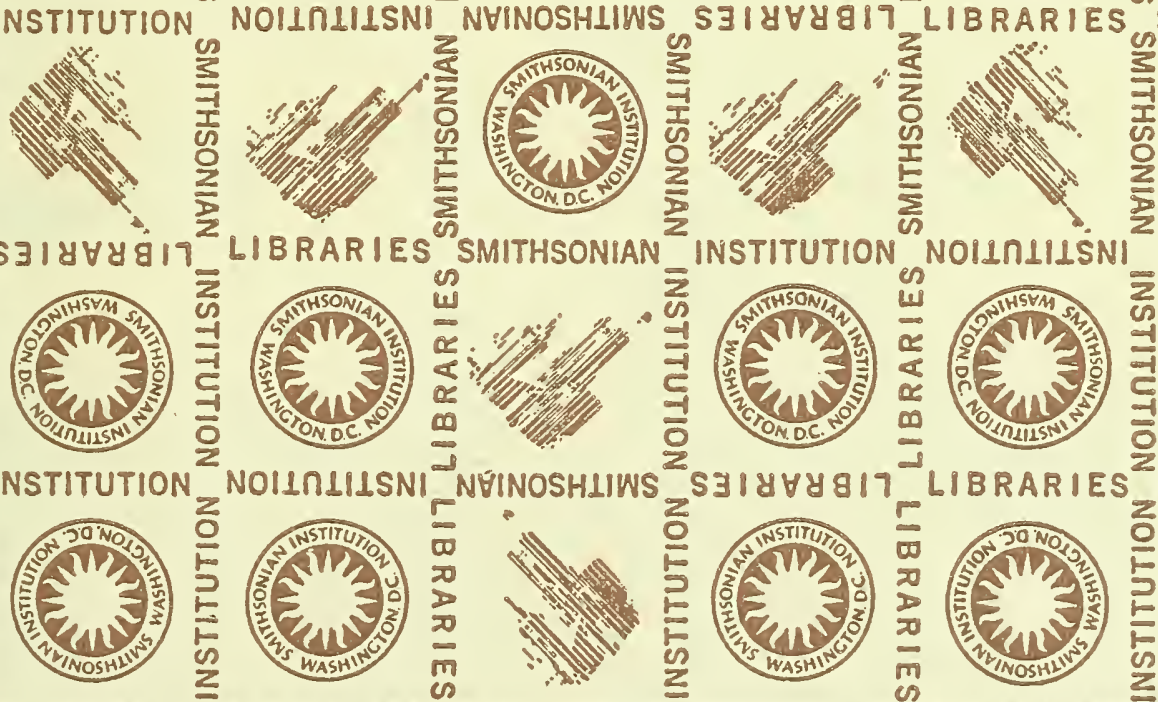



\section{NEW YORK SOCIETY OF}

\section{CERAMIC ARTS}

61st ANNUAL EXHIBITION.

NK

3712

N5N53

1955

CHNREF

MARCH 4th thru MARCH 25th, 1955

COOPER UNION MUSEUM

FOR THE ARTS OF DECORATION 4 th AVE. AND 7 th ST., NEW YORK CITY 
The New York Society of Ceramic Arts was founded in 1892, by Mme. E. Elizabeth Le Prince. It is an organization of Artist-Craftsmen and Sculptors, who believe that trained craftsmen are an essential part of our machine era and that by devoting themselves to the highest standards of workmanship they can be a guiding force in the field of industrial production.

\section{EXECUTIVE BOARD}

President DOROTHY FISH

Ist Vice-President BILLY SPENCER

2nd Vice-President MAURICE HEATON

Treasurer FRANCINE FIERSTEIN

Corresponding Secretary DORIS KLEIN

Recording Secretary GERTRUDE HARTMAN Membership Chairman ROSE KREBS

Ways \& Means Chairman JACK D. WOLFE Publicity Chairmen DON MAVROS, JOSEPH P. GREBANIER Special Events Chairmen ERNA WEILL, ALICE GUNDELFINGER Exhibition Chairmen DOROTHY A. LARSON, PRISCILLA M. PORTER

\section{SHOWN ON COVER:}

Bull-M. Kempe - Tall Bottle-Hui Ka Kwong

Head-J. Woodham - Fish-E. Chandless - Plate-P. Pillin

\section{SHOWN BELOW:}

Large Bottle-J. Grebanier - Large Jug-C. Malten

Sculpture-J. Konzal - Round Plate-R. Blackstone

Animal-G. Englander $\bullet$ Small Bottle-M. Turoff

Rectangular Piece-R. Key-Oberg

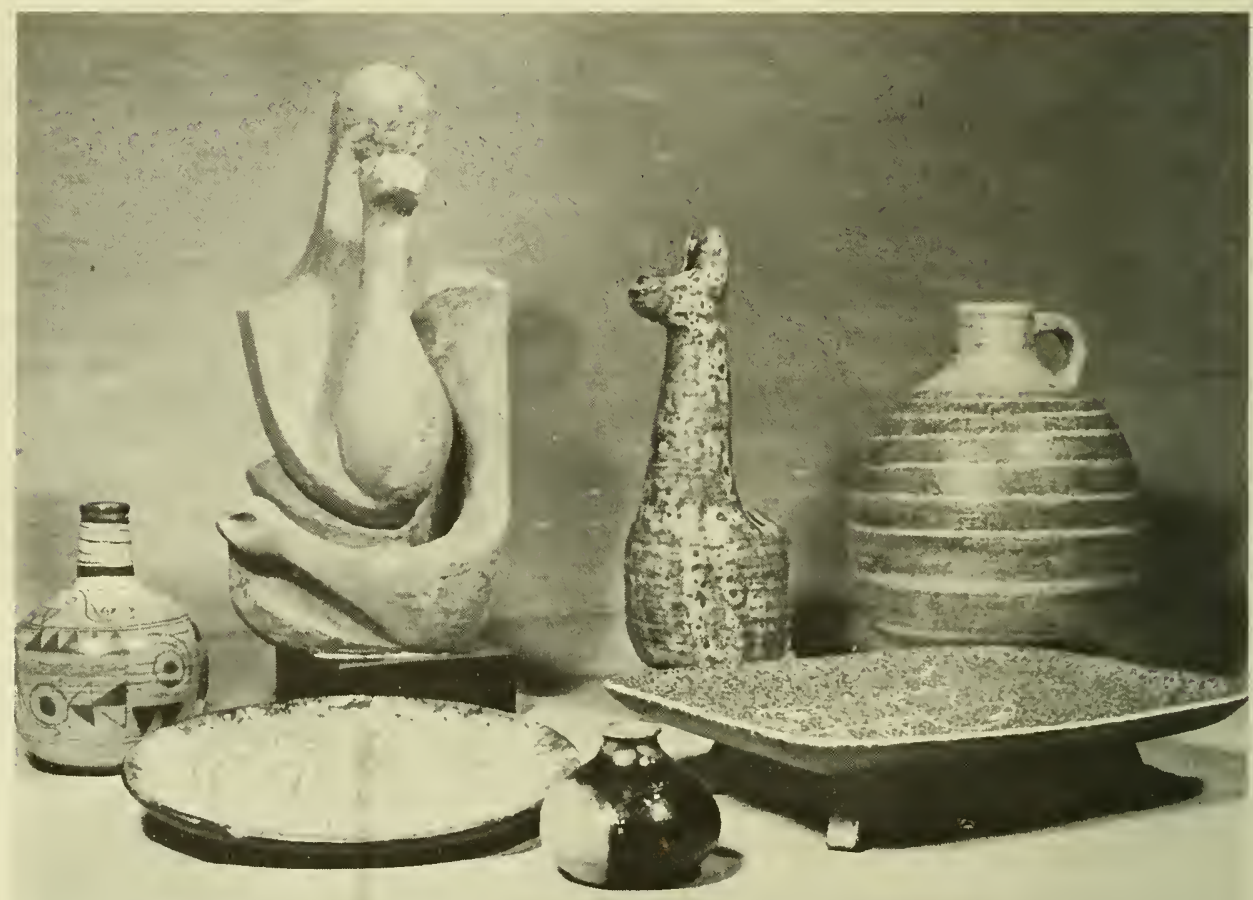




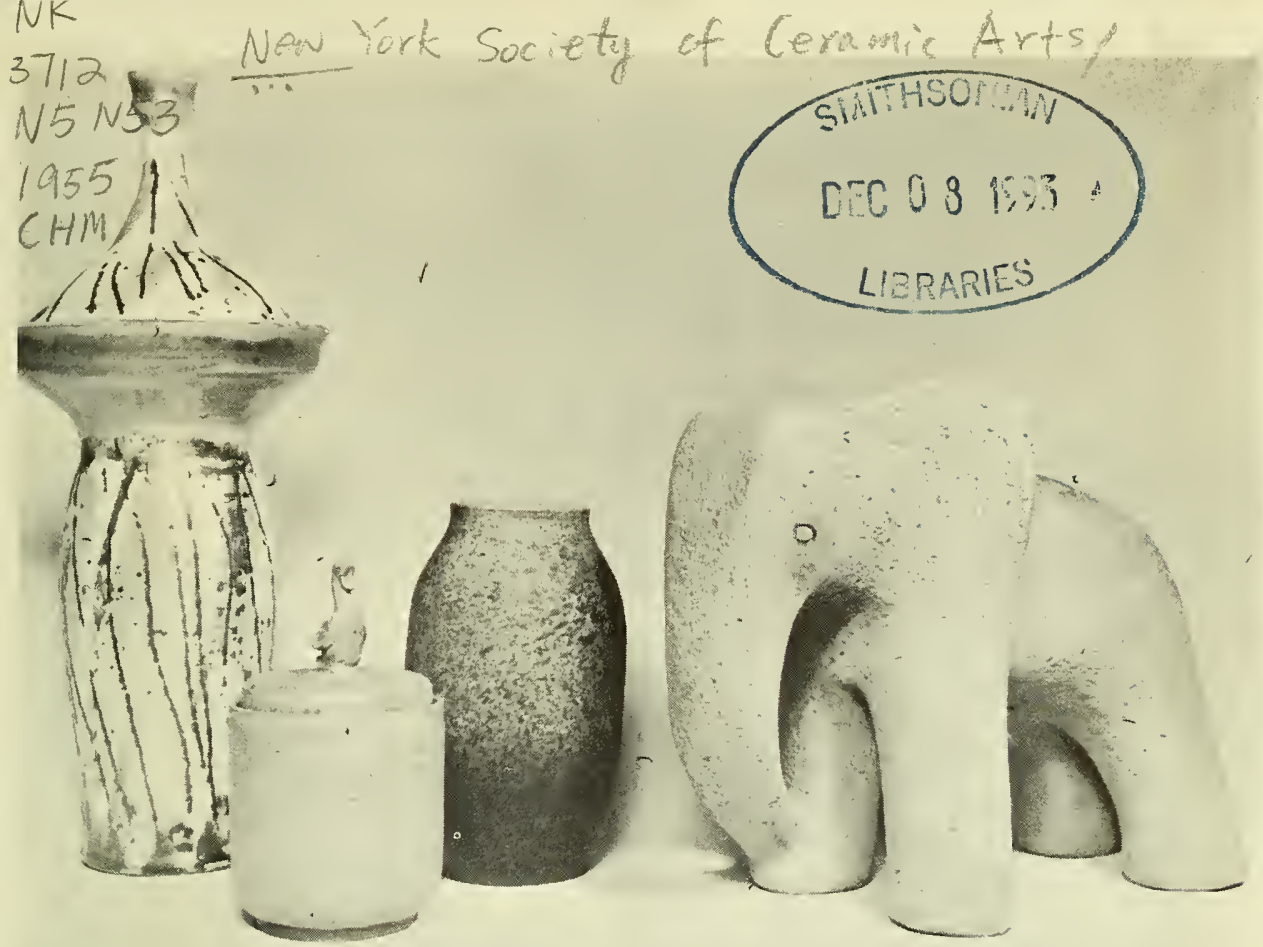

\section{SHOWN ABOVE:}

Tall Jar-Hui Ka Kwong - Small Jar

N. Herz • Vase-D. Jervis - Elephant-M. Kempe

\section{SHOWN ON BACK COVER:}

Glass Bowl-M. Heaton - Owl-P. Blundell

Jar-B. Spencer • Enamel Plate-G. Hartman - Sculpture-R. Krebs

The purpose of the Society may be said to be threefold:

I. To uphold within the group the highest standards of "individual" creative work it is possible to obtain.

2. To bring before the public in as many ways as possible the expression of the creative ceramist - in Sculpture, Pottery, Glass, and Enamel. There is at least one Exhibition of members' work given annually.

3. To give the members of the Society as well as the interested public an educational program which will further the study, understanding and appreciation of creative ceramics.

Craftsmen wishing to join this organization must be sponsored by a professional member and submit three or more pieces of their work to the membership jury. 


\section{J UR Y}

SCULPTURE: M. Kempe, A. Weschler, J. Woodham, L. Duble

non-member, Mr. K. George Kratina, Cooper Union Art School

POTTERY:

GLASS:

ENAMELS:

G. Balsam, A. deCarmel, A. Jacobson, G. Englander

non-member, Mr. Calvin S. Hathaway, Cooper Union Museum

\section{LE C T U R E}

Thursday, March 17th, at 8 PM, at The Museum

Lecture with slides, "SWEDISH and AMERICAN CERAMICS"

By Mr. Preston J. Frazier, Jr., Univ. of Houston, Texas

\section{DEMONSTRATION S}

Demonstrations will be given at the Exhikition Tuesday and Thursday afternoons and evenings, and on Saturdays. The details are posted here at the exhibition.

\section{HOURS OF THE MUSEUM}

Mon., Wed., Fri., and Sat. - 10 AM to 5 PM - Tues. and Thurs. - 10 AM to 9:30 PM

POTTERS' WHEEL FOR DEMONSTRATIONS COURTESY CRAFTOOL INC.

GRASS CLOTH IN CASES FROM CHARLES R. GRACIE, 137 E. 57th ST., N. Y. C.

\section{GREENWICH HOUSE POTTERY}

16 JONES STREET, NYC 14

- Pottery - Glaze Chemistry

- Ceramic Design - Ceramic Sculpture

CH 2.4106 Director Jane Hartsook
CRAFT STUDENTS League of the YWCA-23rd Year

$\begin{array}{lll}\text { Painting } & \begin{array}{c}\text { Bookbinding } \\ \text { Sculpture } \\ \text { Ceramisersmithing } \\ \text { Silk Screen }\end{array} & \begin{array}{c}\text { Enameling } \\ \text { Metalwork } \\ \text { Jewelry }\end{array} \\ \text { Weaving }\end{array}$

Ceramics Metalwork
Silk Screen

Men. Women. Day, Eve. Catalog CE

140 West 22nd St., N.Y.C. CH 3-5747

SHOWN BELOW:

Sculpture-E. Key-Oberg - Mosaic-Rose Krebs - Jar-D. Smith

Small Pitcher-D. Larson - Large Pitcher-D. Klein - Bottle-A. Gundelfinger

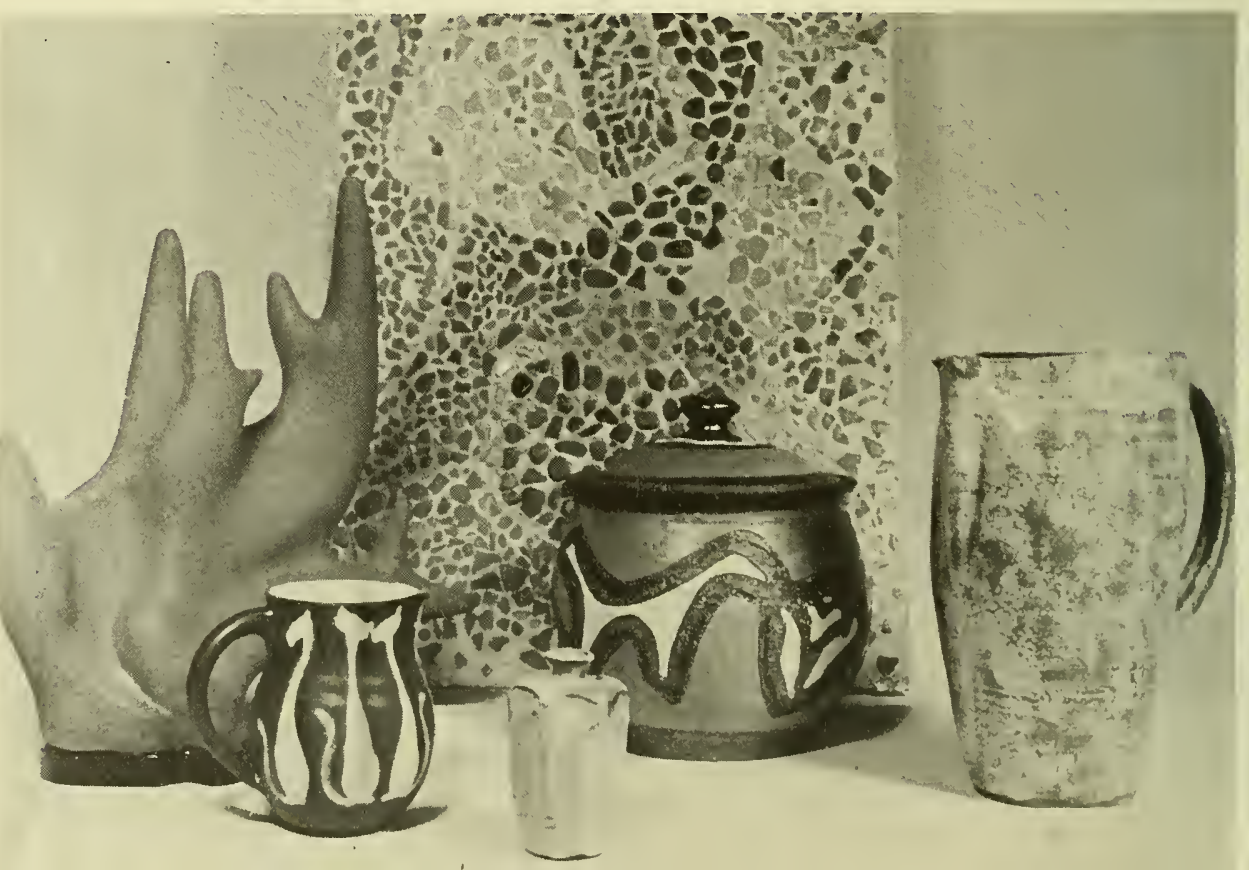


For the finest in Enamels,

Copper Blanks, and Enomeling Equipment.

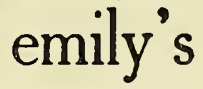

1 Cleorview Ave., Wilmington 3, Del.

Catalogue on request.
CERAMIC ART SUPPLY CO.

45 GROVE ST.

NEW YORK 14, N. Y.

WAtkins $9-8050$

Ceramic \& Metal Enamel Supplies

Paragon Kilns

\section{STEWART CLAY CO., INC.}

133 Mulberry Street, New York City 13

CERAMIC MATERIALS \& EQUIPMENT, CLAYS, TOOLS, WHEELS,

CHEMICALS, GLAZES, ETC., COPPER ENAMEL SUPPLIES

Write for free cotalog.

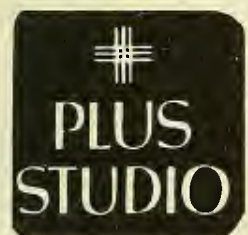

the workshop of unusual lamps shades ceiling wall fixtures

713 MADISUN AVENUE (AT 63rd STREET) TE 8.3858
NEW YORK 21
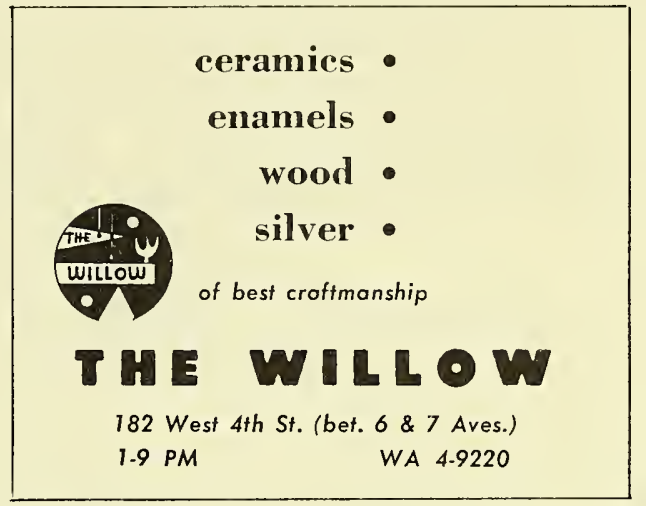

\section{Ceramic}

\section{MATERIALS ANI EQUIPMENT}

A complete line of materials and equipment available. POTTERS WHEELS • KILNS • CLAYS GLAZES • TOOLS • BOOKS, ETC.

\section{ENAMELS}

SPECIAL COPPER SHAPES AND COMPLETE BRACELET SETS ...

Send $10 \mathrm{c}$ for 32 page illustrated catalog JACK D. WOLFE COMPANY, INC. 


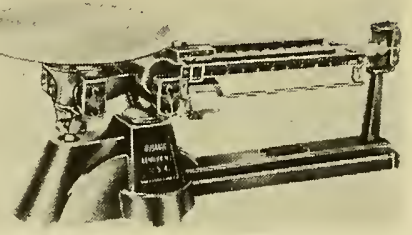

For fast accurate weighing use OHAUS Triple Beam Balances. Featuring a capacity of 2610 grams and a sensitivity of .1 gram these balances are ideal for both the experienced and the beginner in the Ceramic Art field.

Illustrated is the Model \#760 which is supplied with an additional tare beam which enables the user to obtain the net value of materials being weighed in containers.

Model \#750-S is same as \#760 with the exception that it is not supplied with the tare beam. Specifications are as follows:

Front Beam Graduations $10 \times .1$ gram Back Beam Graduations $100 \times 10$ gram Center Beam Graduations 500 × 100 gram. Platform - 6" diameter Stainless Steel Price Model \#760 \$23.00. Price Model \#750-S \$19.15.

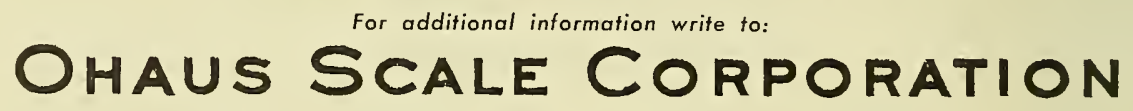
1050 COMMERCE AVENUE, UNION, NEW JERSEY

\section{UNIQUE KILNS of TRENTON, Inc.}

Office: 724 BUNKER HILL AVE.

Plant: 530 SPRUCE ST.

TRENTON, NEW JERSEY

SMALL GAS FIRED KILNS Installations

Alfred University - Ted Randall

Robert Turner - Greenwich House

Carl Espenscheid

HIGH FIRING ELECTRIC KILNS

WITH

KANTHAL ELEMENTS

For use by Brush, Print, Silk Screen \& Spraying

\section{S N E Y D \\ $C O L O R$ \\ $C O M P A N Y$}

China, Semi-Porcelain, Tile, Glass And Enamel Trades

Ceramic Colors Of Perfection 


\section{CRAFTOOL, INC.}

401 Broadway

New York City 13

Potters Wheels, Kick Wheels, Ball Mills,

Tools and Accessories for Ceramic Work.

Send for Complete Catalog

\section{For Years MANUFACTURER of FINE PLASTER MOLDS}

used throughout The United States and also sold to Ceramic Manufacturers in South Africa, South America, Greece, Canada, Alaska, Hawaii, Mexico.

\section{HOLLAND MOLD SHOP}

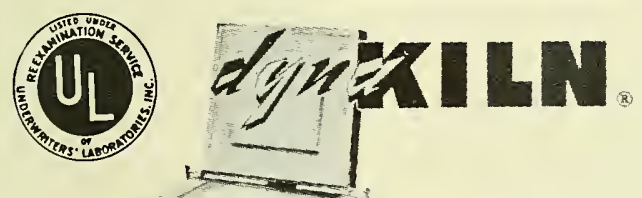

THE FINEST . . . SAFEST KILNS ON THE MARKET!

- 20 standard models priced from $\$ 90.00$. Exclusive DYNA. KILN features: "UL approved throughout, Porcelain element holders, 4-way switch, Pilot Light, 2 peep holes. For art's sake.. . for safety's sake . . . insist on a DYNA-KILN!

\section{ERAMTLIIS KILNS}

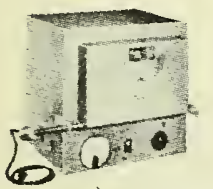

$4^{\prime \prime} \times 8 \frac{1}{2}{ }^{\prime \prime} \times 8^{1 / 4} 4^{\prime \prime}$ Chamber

No. E.49 $\$ 68.00$

$\$ 2.00$ Crating Chg.

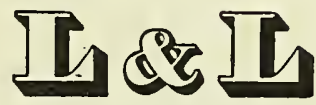

Write for Literature

Electric Kilns

MANUFACTURING COMPANY

Chester 12, Penna. 

14. 告)

SIIYYY 17 LIBRARIES SMITHSONIAN
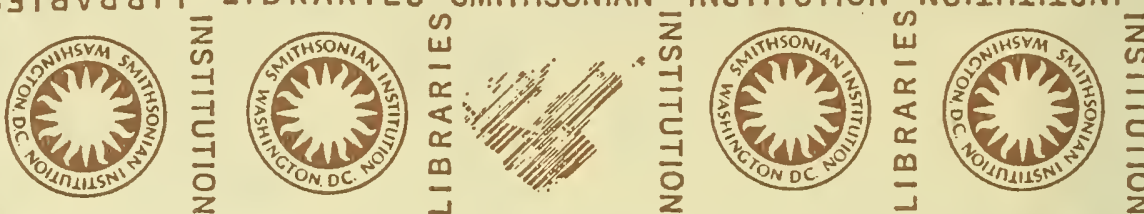

NSTITUTION NOILOIILSNI NVINOSHLINS
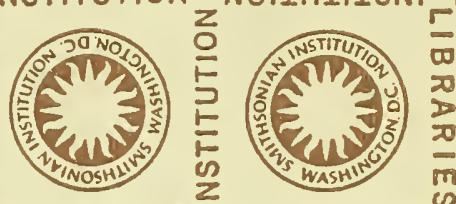

SIYHY817 LIBRARIES
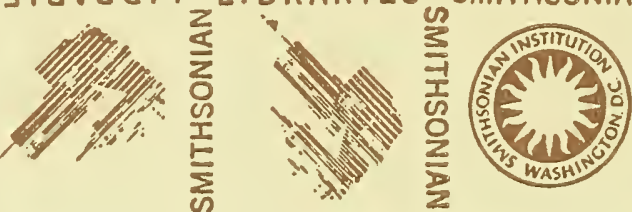

INSTITUTION

NOILNIILSN
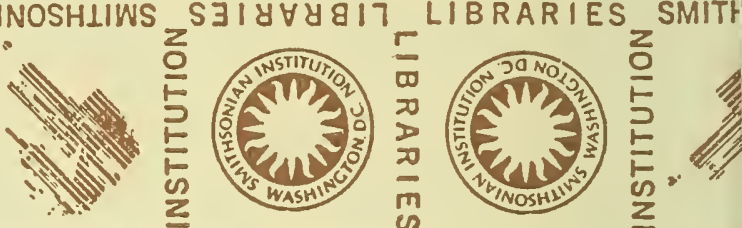
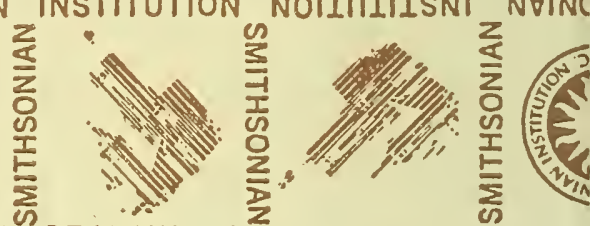

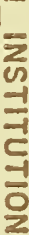

NVINC

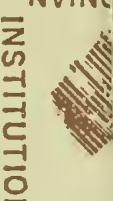

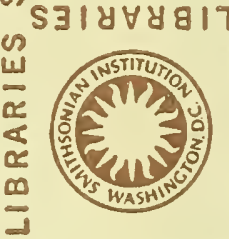

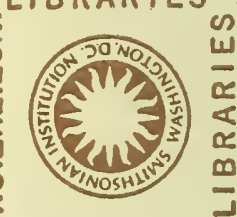

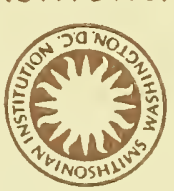
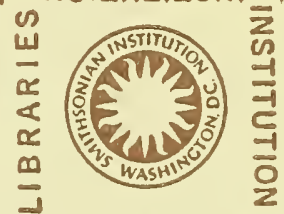

S $318 \forall 4817$
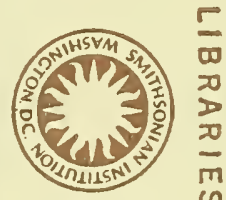

LIBRARIES
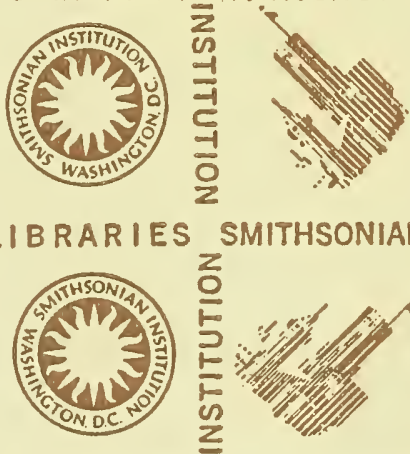

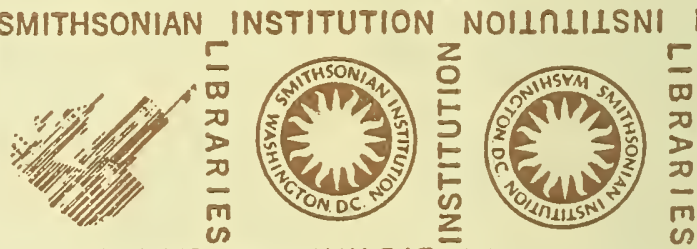

INSTITUTION NOIINIIISNI NVINOSHLIWS
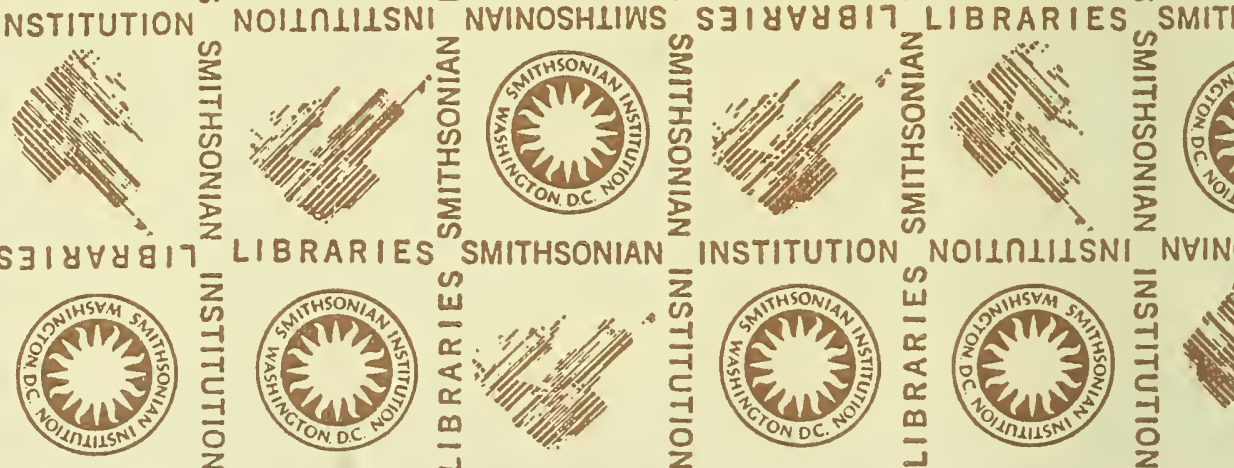

INSTITUTION NOINLIISNI NVINOSHLIWS
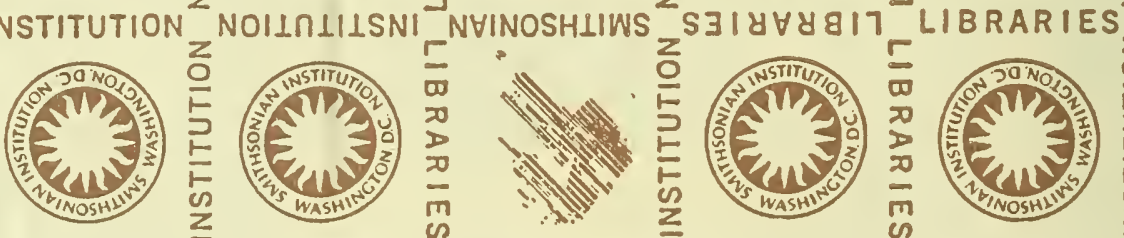

告

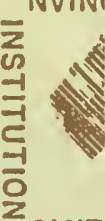

SMITHSONIAN INSTITUTION NOIINLILSNI 


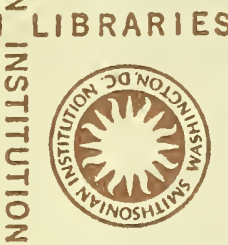

S SMITHSONIAN

INSTITUTION "NOIINIIISNI

NHI
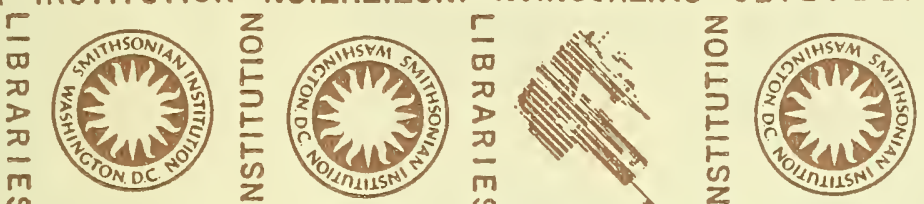

(

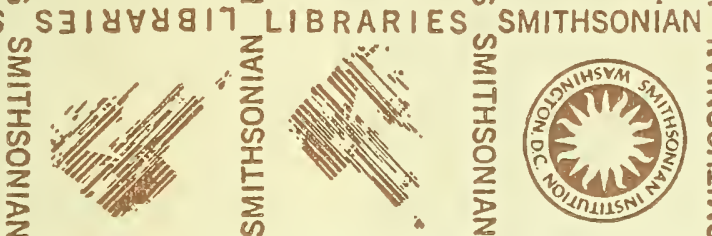
INSTITUTION

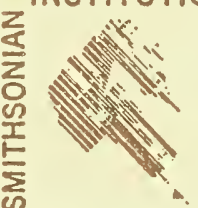

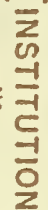

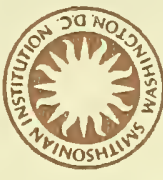

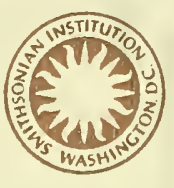

$z$
in
$\frac{1}{6}$
$\frac{-1}{0}$
$z$

LIBRAR!ES SM
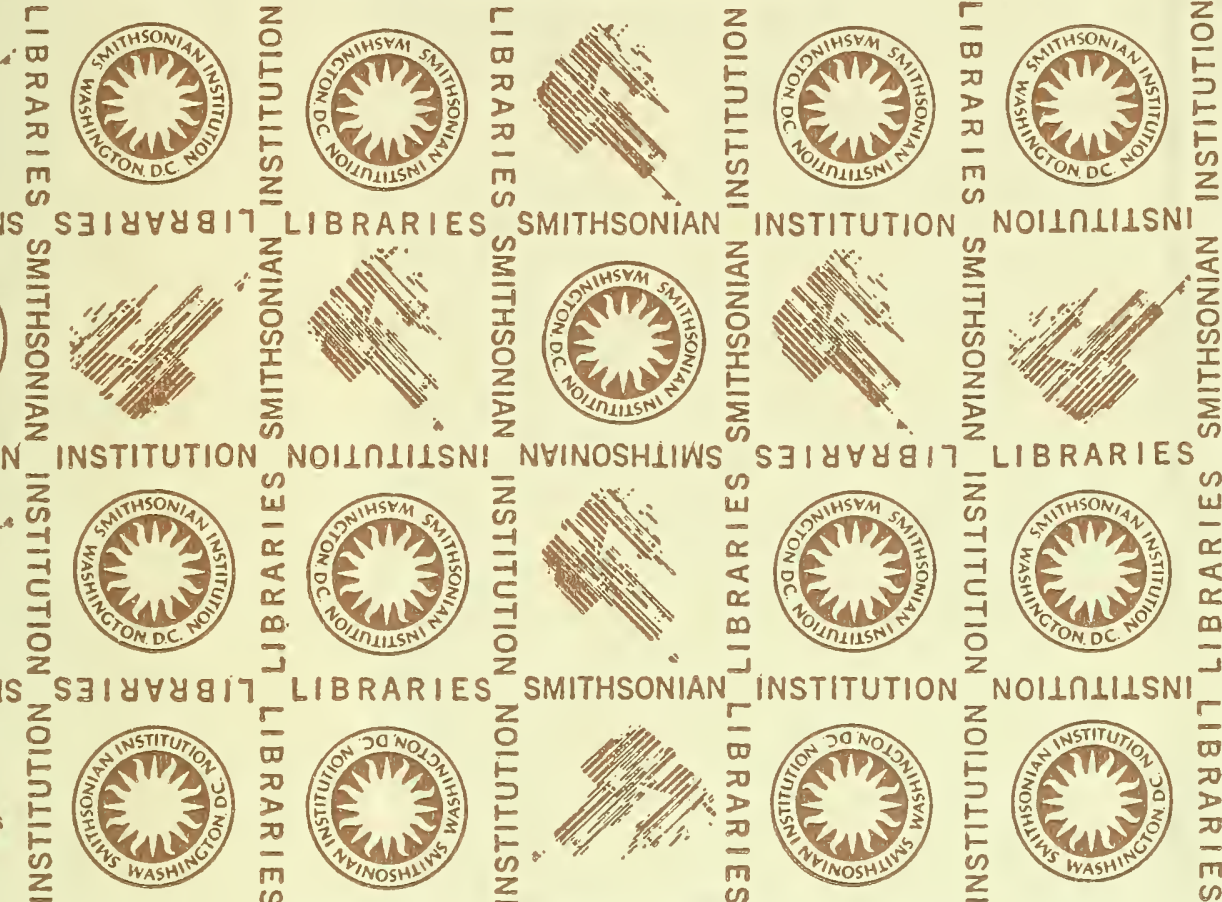

NYI
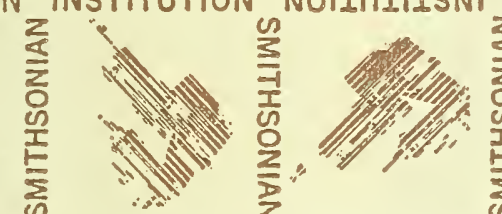

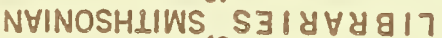
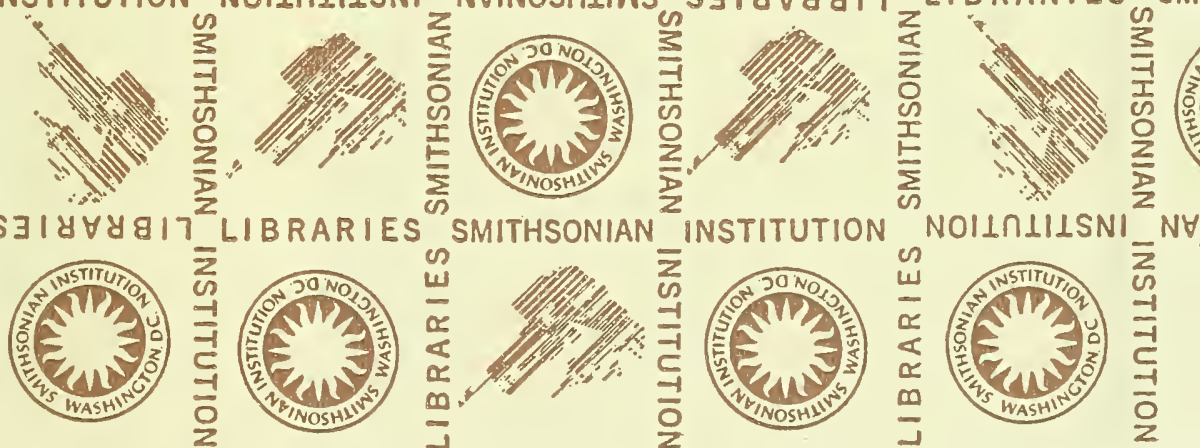

NH

AN INSTITUTION NOILOLILSNI NYINOSHIIWS
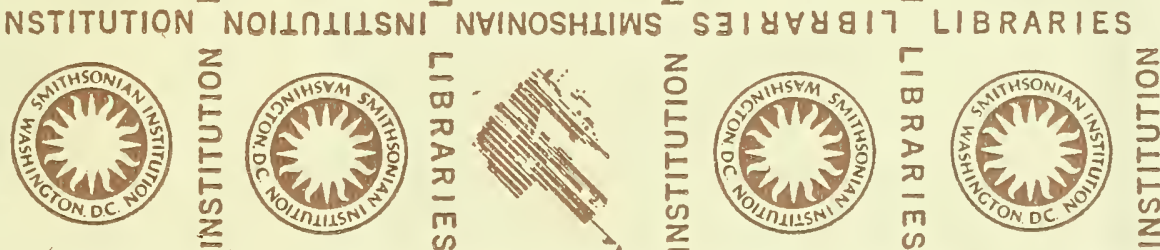

WS SJIYHYG17 LIBRARIES SMITHSONIAN

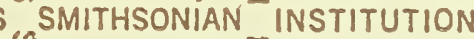

NOILIIISNI NH 
40 Th

17.

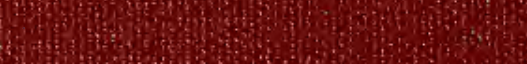

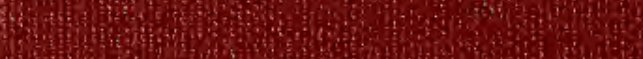

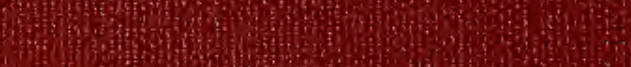

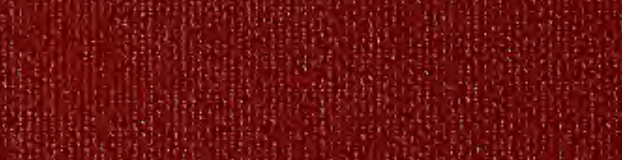

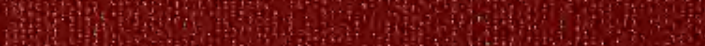
(1)

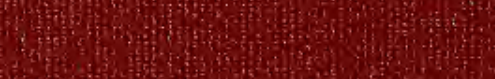

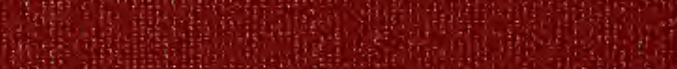

H.

(3)

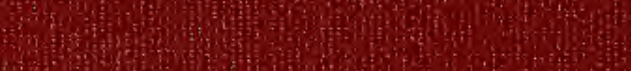

10.

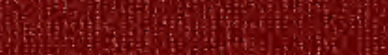

(1)

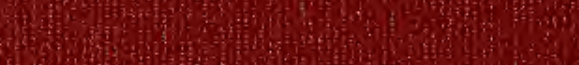

ecto

a

(3)

inting

2.

(n)

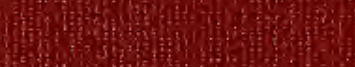

Wing

H.

2.

(1)

(1)

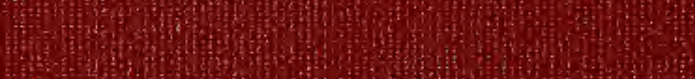

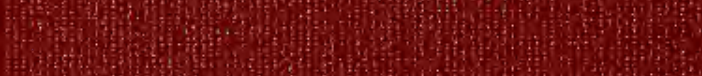

(1)

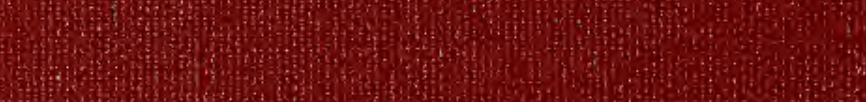

19m

43 (2)

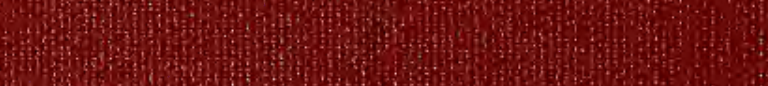

17.

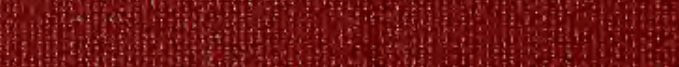

4.

2) 